\title{
Human genome organization is launched with a flourish
}

\section{Washington}

What was five months ago merely an idea for an international council to promote collaboration on the mapping and sequencing of the human genome has now coalesced into a bona fide organization with money in its pocket.

HUGO, the Human Genome Organization, held its first council meeting on the 6 and 7 September in Montreux, Switzerland, and newly elected president Victor McKusick of Johns Hopkins University in Baltimore expects that HUGO will have opened offices around the world by the end of the year.

HUGO was born at a rump session of a Cold Spring Harbor meeting last April. According to McKusick, James Watson, director of the laboratory, Leroy Hood of the California Institute of Technology, Sydney Brenner of the Medical Research Council Laboratory of Molecular Biology in Cambridge and Kenichi Matsubara of Osaka University were HUGO's intellectual godfathers

The European Molecular Biology Organization (EMBO) is the model HUGO intends to follow, and to that end it has incorporated in Switzerland. HUGO will be an extra-governmental organization, but will depend on government contributions for its existence. It will give fellowships, coilduct mapping workshops and issue annual reports.

Another possible function is to serve as a clearing-house for information about the growing number of international groups focusing on the genome project.

The HUGO Council proposed in Montreux that the organization should also start planning for the day when international centres will be set up around the world to do the immense - but mostly routine - task of sequencing identified fragments of DNA. McKusick says it is premature to consider establishing such centres now, but that they will be needed and that it would help to establish HUGO's identity if it were to take the lead in planning for them.

HUGO has established five areas of special interest: data banks, physical mapping/sequencing, other species, ethics and human disease. McKusick says that more cooperation is particularly to be encouraged between those involved in constructing genetic maps of the genome and those involved in physical mapping and sequencing efforts. He also believes that HUGO will have to be conscientious in addressing the ethical issues raised by the mapping effort.

If nothing else, HUGO would command attention based on the stature of its membership. Five of the 42 individu- als on the HUGO Council are Nobel laureates (Watson, Jean Dausset, Renato Dulbecco, Walter Gilbert, Francois Jacob), and the rest represent a Who's Who of molecular genetics. The council membership is international: 12 are from the United States, 7 from Britain, 5 from Germany, 4 from France, 3 from Japan, 2 each from Canada, Holland and Sweden, and one each from Australia, Greece, Italy the Soviet Union and Switzerland.

The Soviet member, Andrei Mirzabekov from the Institute of Molecular Biology of the Soviet Academy of Sciences attended the Montreux meeting.

HUGO does not yet have a fixed budget, but is aiming for several million dollars a year to support its activities. A fund-raising drive is currently underway, directed by Harvard University's Gilbert, who was elected treasurer of HUGO. His selection for the post has an ironic tinge, as Gilbert has recently abandoned attempts to raise capital to start the Genome Corporation, a private effort to complete the mapping and sequencing project (see Nature 332, 387; 1988).

Gilbert is cautious about HUGO's fund-raising, but others are confident that several hundred thousand dollars can be quickly raised to set up HUGO offices in North America, Europe and Japan.

Brenner is credited with having come up with the name for HUGO, but with McKusick as the organization's president, some call it "Victor's HUGO".

Joseph Palca

\section{Forty-year project endangered by NERC's regrouping}

\section{London}

RESTRUCTURING of the research councils in Britain continues with the Natural Environment Research Council (NERC) announcing last week its decision to concentrate oceanographic reserach at one main centre on the campus of the University of Southampton. The move will cost $£ 35$ million and the government has not yet agreed to provide the funds. If the plan goes ahead, Southampton will become "the capital of oceanography in Europe" says Dr John Woods, head of the council's

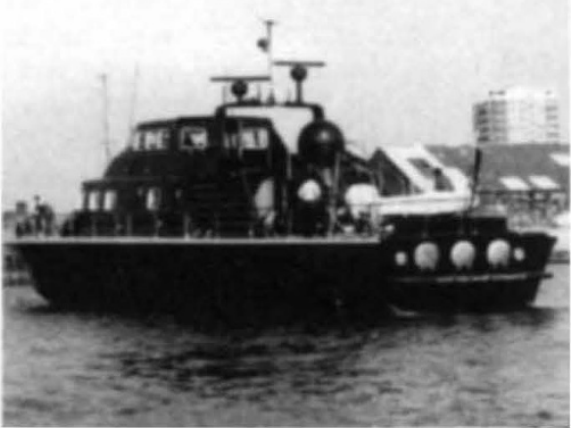

NERC's Deacon Laboratory and the University of Southampton will have the use of the International Maritime Institute's Brave Challenger.

marine sciences directorate. Facilities there will match those of the Marine Biology Laboratory at Woods Hole in Massachusetts and the Scripps Institute of Oceanography in California.

Projects to be run jointly by the council and the university last week received support worth $£ 1$ million from a private trust, the International Maritime Institute, founded recently with the aim of promoting links between oceanographic institutions worldwide. The institute will provide its high-speed vessel Brave Challenger for experiments to measure ocean storms, plankton distribution and to study estuarine environments.

Elsewhere, council support for plankton monitoring is to be withdrawn. A project which has monitored plankton in the north-east Atlantic Ocean and in the North Sea for 40 years continuously is to be the latest victim of the financial problems of the council. It is run by the council's marine laboratory at Plymouth, where researchers are dismayed by the sudden news that the project may be ended within a month. Their data are used in the United States and Canada as well as in several European countries and the researchers are confident they could find alternative funding, given time. The council is expected to make a decision soon on when the project will end.

Christine McGourty

- The secretary of the research council most severely hit by the government's budget cuts, the Agricultural and Food Research Council, last week criticized government policy on science. Speaking at a meeting of the Science Policy Research Group, Professor William Stewart urged the government to withdraw funds from near-market areas of research "more appropriate for direct industry support", in favour of raising support for the research councils from the present "absolute minimum". But Professor Stewart also criticized the complacent attitude of many in the publicly funded sector towards the training for the commercial exploitation of science, saying that "all science undergraduates should take a compulsory course on the commercial exploitation of science". 